\title{
Effects of ATP on Regulatory Volume Decrease in Mouse Cholangiocytes
}

Jae Seung Park

Department of Clinical Pathology, Sohae College, Gunsan 54116, Korea

\section{ATP가 마우스 담관세포의 세포크기 조절에 미치는 영향}

박재승

서해대학 임상병리과

\begin{abstract}
Although the adenosine triphosphate (ATP) efflux pathway is thought to play a major regulatory role in RVD in some cells, including cholangiocarcinoma cells, the role of ATP in regulatory volume decrease (RVD) of normal cholangiocytes is not well defined. Thus, this study was conducted to investigate the role of extra cellular ATP and ATP pathways of BDCCs isolated from normal mice. Changes in cell volume of BDCCS were indirectly assessed by measurement of the cross-sectional area (CSA) by quantitative videomicroscopy. The relative CSA of BDCCs from normal mice increased with hypotonic maneuver to $1.20 \pm 0.02(n=20)$ within $10 \mathrm{~min}$, but decreased to $1.06 \pm 0.03$ at 40 min. Administration of ATP, ATP hydrolase apyrase or the P2 receptor blocker suramin during RVD had no significant effects compared with untreated controls. In addition, treatment with the PKC inhibitors, Bisindolamide I and Ro 31-8220, during RVD had no significant effects when compared with untreated controls. These results indicate that unlike the results from cholangiocarcinoma cells, ATP plays no significant role in the RVD of normal mouse cholangiocytes.
\end{abstract}

Keywords: Adenosine triphosphate, Regulatory volume decrease, Mouse cholangiocytes

This is an Open Access article distributed under the terms of the Creative Commons Attribution Non-Commercial License (http://creativecommons.org/licenses/by-nc/4.0) which permits unrestricted non-commercial use, distribution, and reproduction in any medium, provided the original work is properly cited.

Copyright @ 2016 The Korean Society for Clinical Laboratory Science. All rights reserved.

\author{
Corresponding author: Jae Seung Park \\ Department of Clinical Pathology, Sohae \\ College, 6 Seohae-daegil, Gunsan 54116 \\ Korea \\ Tel: 82-63-460-9255 \\ Fax: 82-63-460-9258 \\ E-mail: jaespark@sohae.ac.kr
}

Received: April 29, 2016

Revised: May 23, 2016

Accepted: May 23, 2016

\section{서 론}

간(liver)은 인체에서 해독작용 및 알코올 분해 등 여러 가지 물질 대사에 있어서 중요한 역할을 수행하고 있으며, 간세포와 담관세포 로 구성되어 있고, 간내 담관세포들은 간의 기능에 많은 영향을 미 치고 있으며, 이러한 세포들의 질환에 의해 다양한 병변을 유발하 게된다[1,2].

담관 세포(cholangiocyte)의 삼투압 조절(osomoregulation) 은 담즙 분비와 변화(bile secretion and modification), 세포내 $\mathrm{pH}$ 조절(intracellular $\mathrm{pH}$ regulation) 그리고 유전자 발현(gene expression) 등 담관 세포 기능에 매우 중요한 역할을 담당하고 있
다[3,4]. 최근, 여러 연구에서 정상 쥐의 간으로부터 분리된 담관 세 포 무리(bile duct cell clusters, BDCCs)와 사람 담관 종양 세포 (human cholangiocarcinoma cell line)가 저장액(hypotonic solution)에 노출되었을 시 세포가 팽대(swelling)되어 그 부피가 증가되고 다시 정상 크기로 되돌아오는 조절 작용이 있음을 알 수 있었다[5]. 담관세포도 다른 세포들과 마찬가지로, 칼륨(potassium, $\mathrm{K}^{+}$)과 염소(chloride, $\mathrm{Cl}^{-}$)이온 전도도(ion conductances)에 의해 부피 감소 조절 기전이 능동적으로 이루어진다[5].

ATP와 ATP 대사는 중요한 신호 전달 분자로서 모든 세포와 조직 에 발현되어 있는 P 2 퓨리너직 수용체(purinergic receptors)의 활성화를 통해 다양한 세포의 기능들을 매개한다[6]. 많은 기능들 
중 어떤 세포에서는 ATP가 퓨리너직 수용체를 통한 자가 신호에 의 해 세포 크기를 조절하는데 있어서 중요한 역할을 하는 것으로 생 각된다[7,8]. 여러 연구에서 어떤 세포에서는 분비된 ATP가 ATP결합 상자(ATP-binding cassette, $\mathrm{ABC}$ )에 의해 전달되어 P2 수용 체를 통해 크기-감수성 $\mathrm{Cl}^{-}$채널(volume-sensitive $\mathrm{Cl}^{-}$channels) 을 조절한다[9]. 간 종양 세포주인(hepatocarcinoma, HTC)에서 ATP가 세포막의 퓨리너직 수용체(purinergic receptors on the plasma membrane)를 활성화시켜, 세포내 칼슘( $\left.\mathrm{i}_{[}\left[\mathrm{Ca}_{2}{ }^{+}\right]\right)$이 증가하 여 칼슘-의존성 과정(calcium-dependent processes)을 활성화 시킴으로써 RVD에 있어서 중요한 역할을 수행하고 있다[10]. 그러 나, 정상 마우스의 담관세포에서 세포내 또는 세포외 칼슘의 농도 증가 실험에서 RVD에 아무런 영향을 미치지 않았다[7]. 그러므로, 이러한 결과에서 정상 담관세포의 RVD 매개에 있어서 세포 외 ATP 그리고 ${ }_{i}\left[\mathrm{Ca}_{2}{ }^{+}\right]$중 어느 것이 주요 역할을 하는지 의문이다.

더 나아가, 어떤 종류의 세포에서는 단백질 카이네이스 C (protein kinase C, PKC)가 세포 크기를 증가(positive)[11]시키거 나 억제(negative)[9]시키는 효과가 있다. 간세포에서는, $\mathrm{PKC}$ 의 한 종류인(isoform) 칼슘- 그리고 포르볼-감수성 $\mathrm{PKCa}\left(\mathrm{Ca}_{2}{ }^{+}-\right.$ and phorbol-sensitive $\mathrm{PKCa}$ )가 있으나, 측정이 되지 않거나 아주 적은 양이 존재하고 있다[12]. 그러므로, $\mathrm{PKCa}$ 는 간세포와 담관세 포를 저장액에 노출하는 동안 세포 크기와 관련 있는 RVD 반응과 연루되어 있을 것으로 보인다. 많은 연구에서 간세포의 대사가 이 루어지는 동안 $\mathrm{PKCa}$ 가 직접적으로 $\mathrm{Cl}^{-}$채널 활성을 조절한다[12]. 우리는 저장액에 노출하는 동안 PKC 저해제(specific PKC inhibitors)를 처리하여 RVD 저해를 알아보았다.

정상 마우스의 간으로부터 분리한 담관세포를 저장액에서 노출 하며 RVD 반응에 있어서 ATP의 역할에 대하여 연구하고자 하였 다. 이를 위해, 마우스 간내 담관 절편(intrahepatic bile duct unit, $\mathrm{IBDUs})$ 의 분리와 같은 방법으로 $\mathrm{BDCCs}$ 준비하였고[13], 단지 담 관강(bile duct lumen)을 형성하지 않은 $\mathrm{BDCCs}$ 를 사용하였다. 마 우스 간으로부터 분리한 담관세포는 다른 담관세포 세포주(cell lines)보다 생리적 상태가 원시적 환경(primitive conditions)에 매 우 가깝고, 이러한 기술은 담관세포의 생물학적 그리고 생리학적 연구에 많은 도움을 준다. 이번 연구의 여러 결과들에서 ATP와 $\mathrm{PKC}$ 가 정상 마우스 담관세포의 RVD에 있어서 중요한 역할을 하지 않는다는 것을 알 수 있었다.

\section{재료 및 방법}

\section{1. 실험재료}

Matrigel은 Collaborative Biomedical (Bedford, MA, USA)에
서, collagenase B는 Roche Applied Science (Penzberg, UP, Germany)에서, Pronase는 Calbiochem (San Diego, CA, USA)에 서 구입하여 사용하였고, Liebowitz-15 (L-15), minimum essential medium (MEM), $\alpha$-minimum essential medium, L-glutamine, gentamicin, 그리고 fetal calf serum 은 Invitrogen (Waltham, MA, USA)에서 구입하였고, 그 외 시약과 배양액 보충 제는 Sigma (St. Louis, MO, USA)에서 구입하여 사용하였다.

\section{2. 용액}

HEPES가 포함된 등장액(isotonic solution)과 저장액의 구성 성분은 다음과 같다 [5,8]. 등장액은 $\mathrm{HEPES}$ 용액 $\left(\mathrm{pH} 7.4,37^{\circ} \mathrm{C}\right)$ 에 $\mathrm{NaCl}$ (40\%)과 자당(sucrose)을 포함하여 사용하였으며, 저장액은 자당을 제외한 나머지 구성은 등장액과 같다.

\section{BDCCs 분리}

정상 숫컷 C57BL6 마우스(4 14주)를 Charles River (Wilmington, $\mathrm{MA}$ )에서 구입하여 사용하였다. 마우스 $\mathrm{BDCCs}$ 의 분리 는 전과 동일한 방법을 이용하였다 [5,13]. 요약하면, 마우스를 마취 한 후간문맥을 통해 collagenase B를 포함하고 있는 Hanks'용액 을 순환시킨 후 간을 떼어내고 간을 둘러싸고 있는 막과 간세포를 제거하고, 마지막으로 여러 가지 효소 collagenase, DNase, Pronase 그리고 hyaluronidase를 포함하고 있는 MEM 용액을 처 리하였으며, 100- and 30-mm meshes (Tetko, Lancaster, NY, $\mathrm{USA}$ 를 이용하여 여과 시키고, 30-mm mesh에 남아있는 조각들 을 MEM 배지 3 6 mL을 이용하여 수거하였다[5,13]. 수거한 조각 들을 세포 배양 용기에 들어있는 matrigel로 코팅된 작은 유리 조각 (2 4 mm)위에 분주하여 $5 \% \mathrm{CO}_{2}, 37^{\circ} \mathrm{C}$ 에서 $24 \sim 72 \mathrm{~h}$ 동안 배양 하여 실험에 사용하였다. 분리한 BDCCs의 특성은 담관 세포-특이 사이토케라틴-19 항체(cholangiocyte-specific cytokeratin-19 antibody)를 이용하여 알아보았다[14]. 배양된 BDCCs는 기능 연 구를 한 뒤 tryphan blue를 이용하여 세포 생존율을 검사 하였다.

\section{4. 비디오현미경을 이용한 세포 크기조절 반응의 정량 측정}

비디오현미경을 이용하여 BDCCs의 횡단면(cross-sectional area, $\mathrm{CSA}$ )을 측정하였다. 비디오현미경을 이용한 횡단면의 간접 적인 측정은 세포 크기를 정확하게 측정 할 수 있다. $\mathrm{BDCCS}$ 를 matrigel이 코팅된 유리조각에서 밤새 배양한뒤 현미경에 부착되 어 있는 온도조절기에 옮겨 $37^{\circ} \mathrm{C}$ 에서 $10 \sim 20$ 분 동안 등장액에 노 출시킨 후 각각의 실험에 따라 시약을 처리하고 매 1 5분마다 영 상을 측정하였다[5]. BDCCs의 삼투 조절반응은 Olympus IX-70 (Olympus Inc., Melville, NY, USA) 또는 Leica DMIR (Leica 
Microsystems, Inc., Buffalo, NY, USA) 도립현미경을 이용하여 횡단면의 변화를 측정하였다. 현미경을 컴퓨터에 연결하여 OpenLab 영상 분석 소프트웨어(Improvision, Boston, MA, USA) 를 이용하여 분석하였다. 각각의 $\mathrm{BDCCs}$ 실험그룹과 대조그룹 모 두 tryphan blue 염색으로 생존율 검사를 하였다.

\section{5. 통계분석}

비디오현미경으로 측정된 모든 결과들은 산술평균 \pm S.E.로 처 리하였다. 통계처리는 INSTAT statistical computer program (GraphPad Software, San Diego, CA, USA)을 이용하여 Student's t-tests로 처리하였다.

\section{결 과}

\section{1. 세포외 ATP (extracellular ATP)가 RVD에 미치는 영향}

$\mathrm{RVD}$ 에 대한 ATP의 영향을 보기 위하여, 세포외 ATP를 담관세 포에 처리하였다. Fig. 1 에서 보는바와 같이, BDCCs는 저장액에서 10 분 동안에 빠르게 CSA가 증가 하였으며, 그 후 정상 크기로 되돌 아 왔다[14]. 담관세포를 저장액에 노출하며 $10 \mu \mathrm{M}$ 또는 $1 \mathrm{mM}$ ATP를 처리한 결과 RVD에 아무런 영향이 없었다(Fig. 1). 이러한 결과에서 세포외 ATP 처리는 담관세포에 아무런 영향을 주지 않음 을 알 수 있었다.

\section{2. 아피라아제(apyrase) 처리가 마우스 담관세포의 RVD에 미치는 영향}

RVD에 대한 ATP의 역할을 알아보기 위하여, ATP 가수분해 효 소인 아피라아제의 RVD에 대한 효과를 보기 위해 담관세포에 처리

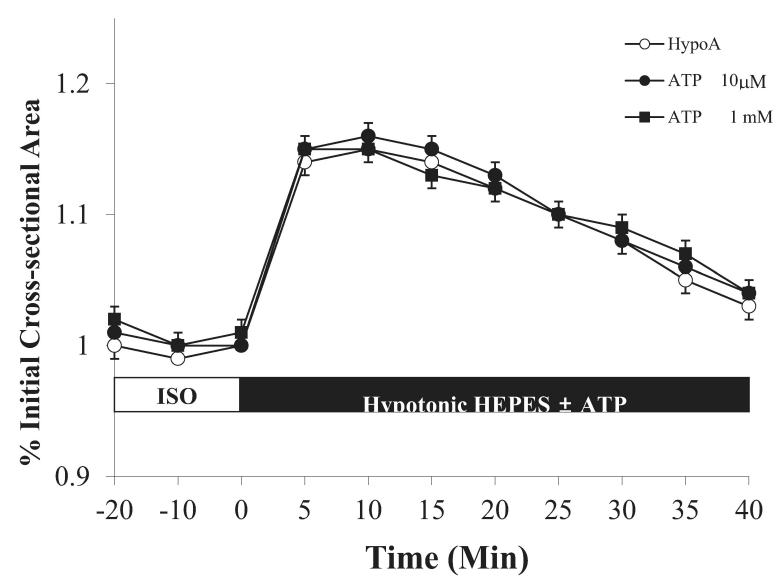

Fig. 1. Effect of ATP on RVD of normal mouse BDCCs. Coadministration of ATP during hypotonic maneuver had no significant effect on the RVD of normal mouse BDCCs $(n=10)$, compared to the untreated controls.
하여 보았다. Fig. 2에서 보듯이, 아피라아제(3 U/mL)[15] 처리는 정상 담관세포에서 RVD에 아무런 영향이 없었다. 이러한 결과들 은 아피라아제에 의한 세포외 ATP의 고갈이 정상 담관세포의 RVD 에 아무런 영향이 없었고, 그러므로 저장액에서 세포로부터 ATP가 분비되어 세포외 ATP의 증가는 정상 담관세포의 RVD에 아무런 영 향이 없을 것으로 추측된다.

\section{3. 슈라민(suramin)이 담관세포의 RVD에 미치는 영향}

ATP 신호를 전달하는 퓨리너직 수용체의 RVD에 대한 영향을 보기위하여, P2X 와 P2Y 퓨리너직 수용체 차단제(blockers)인 슈 라민을 처리하였다. Fig. 3에서 보는 바와 같이, 슈라민(suramin, $100 \mu \mathrm{M})[15]$ 을 담관세포에 처리하여 RVD에 미치는 영향을 알아

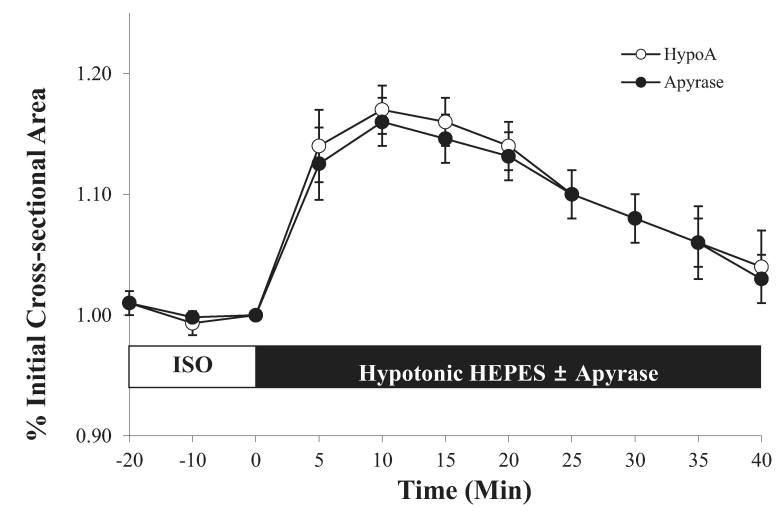

Fig. 2. Effect of Apyrase on RVD of normal mouse BDCCS. Coadministration of Apyrase $(3 \mathrm{U} / \mathrm{mL})$ during hypotonic maneuver had no significant effect on the RVD of normal mouse BDCCS $(n=10)$, compared with the untreated controls.

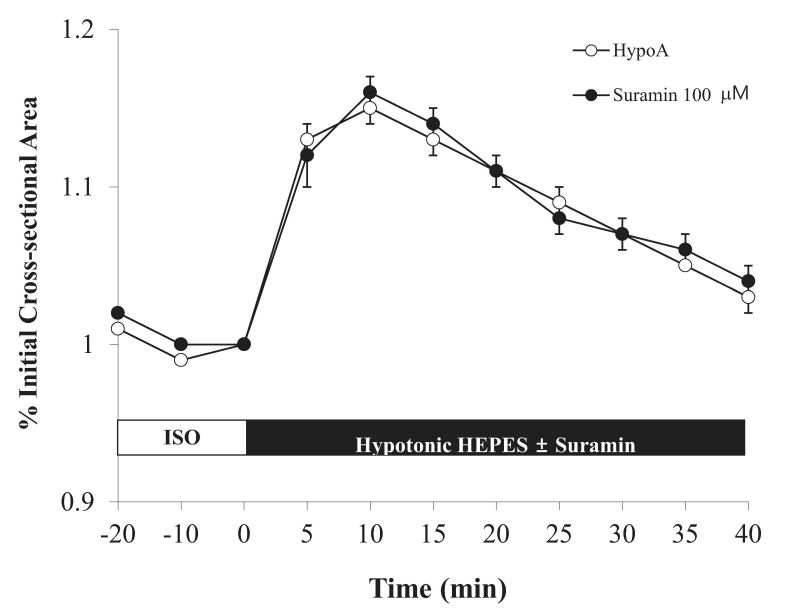

Fig. 3. Effect of Suramin on RVD of normal mouse BDCCs. Coadministration of Suramin $(100 \mu \mathrm{M})$ during hypotonic maneuver had no significant effect on the RVD of normal mouse BDCCs ( $n=9)$, compared to the untreated controls. 


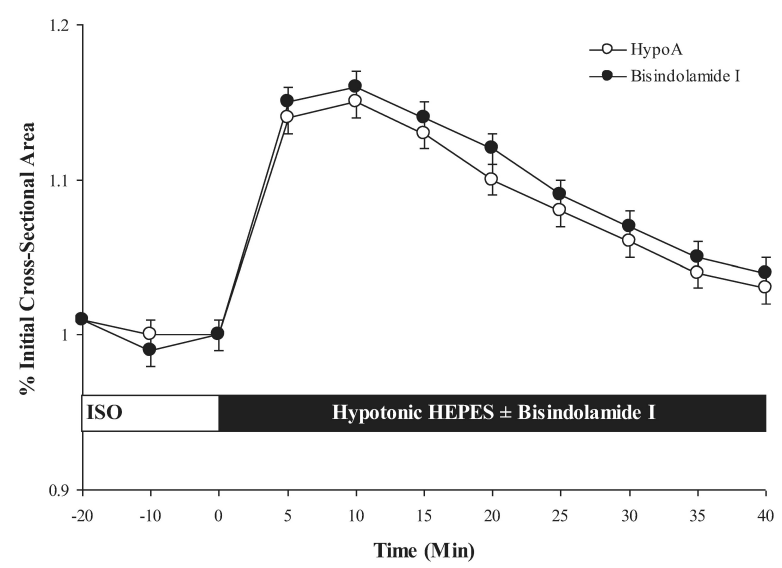

Fig. 4. Effect of PKC inhibitor, Bisindolamide I on RVD of normal mouse BDCCs. Coadministration of Bisindolamide I (100 $\mu \mathrm{M})$ during hypotonic maneuver had no significant effect on the RVD of normal mouse BDCCs $(n=7)$, compared to the untreated controls.

보았으나 아무런 영향을 주지 않았다. 이러한 결과로, 퓨리너직 수 용체를 통한 ATP 신호의 신호 전달은 정상 담관세포의 RVD에 있어 서 중요한 영향이 없음을 알 수 있었다.

\section{PKC 저해제가 담관세포 RVD에 미치는 영향}

단백질 카이네이스 C (PKC) 경로가 RVD에 미치는 영향을 알아 보기 위하여 담관세포에 PKC 저해제(inhibitors)를 처리하여 보았 다. Fig. 4에서 보는 바와 같이, PKC 저헤제인 비신돌아마이드 I (Bisindolamide I, $100 \mathrm{nM}$ )이 RVD에 아무런 영향을 주지 않았다. 또한 다른 PKC 저해제인 Ro 31-8220 (100 nM)를 처리 하여 본바 담관세포의 RVD에 아무런 영향을 주지 않았다(Fig. 5). PKC 신호 경로는 담관세포의 RVD에 있어서 주요 역할을 하지 않음을 알 수 있었다.

\section{고 찰}

담관세포의 크기 조절은 세포의 다양한 기능인 대사, 이온 전달, 담즙분비, 그리고 유전자 발현 등에 있어서 중요한 영향을 준다 [16]. 많은 연구에서 ATP가 어떤 세포에서는 세포 크기 조절에 중 요한 역할을 수행하고 있는 것으로 알려져 있다[3,9]. 이것은 ATP 와 관련이 있는지 또는 ATP-연결 경로를 조절하는지 의견이 다양 하며, 그리고 세포 크기 조절에 있어서 퓨리너직 수용체 경로가 세 포의 RVD에 있어서 세포밖의 ATP 전달에 의해 발생하는지에 대해 서도 논란이 있다[3,9]. 담관세포의 RVD에 있어서 ATP의 역할을 알아보기 위하여, 이와 관련된 다양한 연구를 하였다.

세포외 ATP에 의한 세포 크기 조절을 직접적으로 알아보기 위하

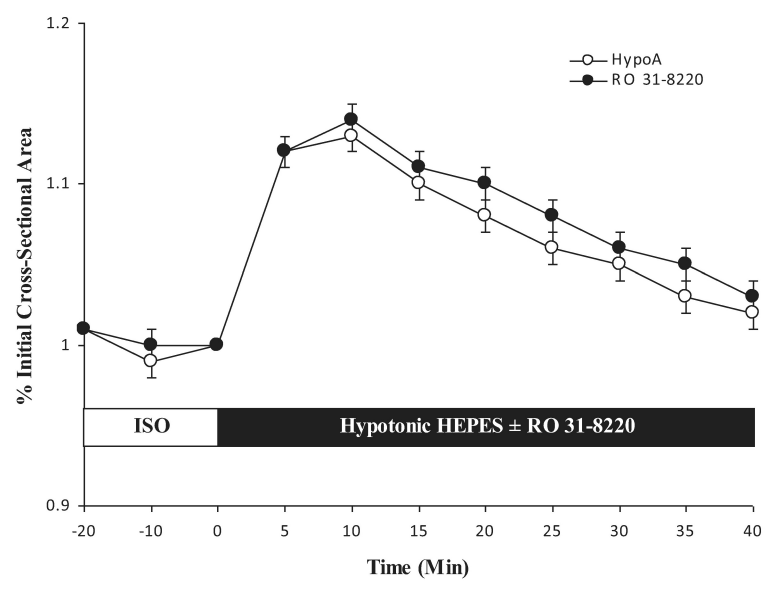

Fig. 5. Effect of PKC inhibitor, Ro 31-8220 on RVD of normal mouse BDCCs. Coadministration of Ro 31-8220 (100 $\mu \mathrm{M})$ during hypotonic maneuver had no significant effect on the RVD of normal mouse BDCCs $(n=10)$, compared to the untreated controls.

여, 정상 마우스의 담관세포를 저장액에 노출시키며 ATP를 처리하 여 본 바, 세포외 ATP는 RVD에 아무런 영향을 주지 않았으며, 또한 ATP 가수분해 효소인 아피라아제를 저장액에 노출하여 처리하였 으나 담관세포의 RVD에 아무런 영향을 주지 않았다. 이러한 결과 에서 ATP가 담관세포의 RVD에 있어서 주요 조절인자로서 작용을 하는지에 대해 궁금하게 하였다.

더 나아가, 여러 연구에서 추측컨대, 분비된 ATP는 핵산-게이트 이온 채널(nucleotide-gated ion channel)인 P2X 그리고 G-단백 질이 결합된(G-protein coupled) P2Y를 통해 퓨리너직 신호를 전 달하며, RVD에 영향을 준다고 하였다[17,18]. P2X와 P2Y 퓨리너 직 수용체 저해제인 슈라민(suramin)을 이용하여 RVD에서 퓨리 너직 수용체의 역할을 담관세포에서 알아보았으나[19] RVD에 아 무런 영향이 없었다.

$\mathrm{PKCa}$ 신호 경로는 저장액에서 세포 팽대에 관여한다고 보고되 었다[20,21]. PKCa는 칼슘-감수성 $\mathrm{PKC}\left(\mathrm{Ca}_{2}{ }^{+}\right.$-sensitive $\left.\mathrm{PKC}\right)$ 이 며 하나의 펩타이드 사슬(a single peptide chain)에 4 개의 보존 영 역(conserved domains)을 갖고 있다. 이 영역은 두 가지 영역으로 나누어지는데, 조절 영역(regulatory domains)인 C1 [phorbol 12-myristate 13-acetate (PMA) 결합]과 디아실글리세롤[diacylglycerol (DAG)]/C2 (칼슘 결합, bind Calcium) 그리고 촉매 영 역(catalytic domains)인 C3 (ATP 결합)이다[21]. PKC 경로 저해 제인 비신돌아마이드(bisindolamide) I과 Ro 31-8220 를 BDCCs 에 처리하였으나 RVD에 아무런 영향을 주지 않았으며, 중요한 역 할을 하지 않음을 알 수 있다.

이러한 결과에서 볼 때 칼슘, ATP, 퓨리너직 수용체, 그리고 PKC 경로는 담관세포의 RVD에 있어서 중요한 역할을 하지 않음을 알 
수 있었다. 원시적 담관세포들(primary cholangiocytes)의 결과 들은 암 세포주들과 다른 결과를 보였으며, 담관세포에 대해서는 아직도 정확하게 밝혀지지 않았다. 그러므로 담관세포의 RVD에 대한 신호 경로를 이해하기 위해서는 더 많은 연구가 필요하다. 연구를 통해 어떤 신호 경로들 또는 이온 채널들이 담즙 울체성 간질환(biliary cholestatic liver disease)의 치료에 효과적인지를 밝혀야 할 것이다.

\section{요 약}

ATP 분비 경로는 담관세포종 세포주를 포함한 일부 세포의 RVD 조절에 있어서 주요한 조절 역할을 수행할 것으로 생각되나, 정상 담관세포의 RVD에 있어서의 역할은 잘 알려져 있지 않다. 정상 담 관세포의 RVD에 있어서 세포 외 ATP와 ATP 경로의 역할을 알아보 기 위하여, 정상마우스에서 담관세포를 분리하여 연구에 이용하였 다. $\mathrm{BDCCs}$ 의 크기 변화는 정량측정 비디오현미경을 이용하여 횡 단면을 간접 측정하였다. 정상마우스의 BDCCs의 횡단면은 저장 액에서 노출한 후 10 분에 $1.20 \pm 0.02(\mathrm{n}=20)$ 이었으나, 40 분에는 $1.06 \pm 0.03$ 로 감소하였다. ATP와 ATP 가수분해 효소인 아피라아 제 또는 P2 수용체 차단제인 슈라민 RVD 과정 중에 처리 하였으나 처리하지 않은 대조군과 중요한 차이를 보이지 않았다. 더 나아가, PKC 저해제인 비신돌아마이드 I 과 Ro 31-8220을 처리하여 RVD 에 미치는 영향을 알아 보았으나 대조군과 중요한 차이를 보이지 않았다. 이러한 결과들에서 정상 마우스 담관세포는 담관세포종 세 포주와 다른 결과를 보였으며, 정상 마우스의 RVD에 있어서 ATP 는 중요한 역할을 하지 않음을 알 수 있었다.

\section{Acknowledgements: None}

Funding: None

Conflict of interest: None

\section{References}

1. Neil K. Liver and Biliary Diseases. 2st ed. Maryland: Williams \& Wilkins A Waverly Company; 1996.

2. Lee MY, Kim WS, Lim Y. Effects of Green Tea Catechins (GTC) on the Treatment of Hangover and Prevention of Liver Disease. Korean J Clin Lab Sci. 20014;46:131-135.

3. Braunstein GM, Roman RM, Clancy JP, Kudlow BA, Taylor AL, Shylonsky VG, et al. Cystic fibrosis transmembrane conductance regulator facilitates ATP release by stimulating a separate ATP release channel for autocrine control of cell volume regulation. J Biol Chem. 2001;276:6621-6630.

4. Feranchak AP, Fitz JG, Roman RM. Volume-sensitive purinergic signaling in human hepatocytes. J Hepatol. 2000;33:174-182.

5. Cho WK. Characterization of regulatory volume decrease in freshly isolated mouse cholangiocytes. Am J Physiol Gastrointest Liver Physiol. 2002;283:G1320-1327.

6. Buell G, Collo G, Rassendren F. P2X receptors: an emerging channel family. Eur J Neurosci. 1996;8:2221-2228.

7. Ishii T, Hashimoto T, Ohmori H. Hypotonic stimulation induced $\mathrm{Ca}^{2+}$ release from IP3-sensitive internal stores in a green monkey kidney cell line. J Physiol. 1996;493:371-384.

8. Park JS, Choi YJ, Siegrist VJ, Ko YS, Cho WK. Permissive role of calcium on regulatory volume decrease in freshly isolated mouse cholangiocytes. Pflugers Arch. 2007;455:261-271.

9. Wang Y, Roman R, Lidofsky SD, Fitz JG. Autocrine signaling through ATP release represents a novel mechanism for cell volume regulation. Proc Natl Acad Sci. USA 1996;93:12020-12025.

10. Feranchak AP, Roman RM, Schwiebert EM, Fitz JG. Phosphatidylinositol 3-kinase contributes to cell volume regulation through effects on ATP release. J Biol Chem. 1998;273:1490614911.

11. Verdon B, Winpenny JP, Whitfield KJ, Argent BE, Gray MA. Volume activated chloride currents in pancreatic duct cells. J Membr Biol. 1995;147:173-183.

12. Wang Y, Roman RM, Schlenker T, Hannun YA, Raymond JR, Fitz JG. Cytosolic calcium and protein kinase C (alpha) couple cellular metabolism to membrane K1 permeability in a human biliary cell line. J Clin Invest. 1997;99:2890-2897.

13. Cho WK, Mennone A, Boyer JL. Isolation of functional polarized bile duct units from mouse liver. Am J Physiol Gastrointest Liver Physiol. 2001;280:G241-246.

14. Cho WK, Siegrist VJ, Zinzow W. Impaired regulatory volume decrease in freshly isolated cholangiocytes from cystic fibrosis mice: implications for cystic fibrosis transmembrane conductance regulator effect on potassium conductance. J Biol Chem. 2004;279:14610-14618.

15. Roman RM, Feranchak AP, Salter KD, Wang Y, Fitz JG. Endogenous ATP release regulates $\mathrm{Cl}$ - secretion in cultured human and rat biliary epithelial cells. Am J Physiol. 1999;276;G1391-1400.

16. Häussinger D. Regulation and functional significance of liver cell volume. Prog Liver Dis. 1996;14:29-53.

17. Abbracchio MP, Boeynaems JM, Barnard EA, Boyer JL, Kennedy C, Miras-Portugal M T, et al. Characterization of the UDP-glucose receptor (re-named here the P2Y14 receptor) adds diversity to the P2Y receptor family. Trends Pharmacol Sci. 2003; 24:52-55.

18. Ralevic V, Burnstock G. Receptors for purines and pyrimidines. Pharmacol Rev. 1998;50:413-492.

19. Ollivier H, Pichavant-Rafini K, Puill-Stephan E, Calves P, Nonnotte L, Nonnotte G. Effects of hypo-osmotic stress on ATP release in isolated turbot (Scophthalmus maximus) hepatocytes. Biol Cell. 2006;98:427-437.

20. Tamma G, Procino G, Svelto M, Valenti G. Hypotonicity causes actin reorganization and recruitment of the actin-binding ERM protein moesin in membrane protrusions in collecting duct principal cells. Am J Physiol Cell Physiol. 2007;292:C14761484.

21. Roman RM, Bodily KO, Wang Y, Raymond JR, Fitz JG. Activation of protein kinase Calpha couples cell volume to membrane $\mathrm{Cl}^{-}$ permeability in HTC hepatoma and Mz-ChA-1 cholangiocarcinoma cells. Hepatology. 1998;28:1073-1080. 